\title{
PENGARUH PENAMBAHAN ABU CANGKANG SAWIT DAN LIMBAH CRUMB RUBBER TERHADAP SIFAT FISIK DAN MEKANIK VULKANISAT HANDGRIP RUBBER
}

\section{THE EFFECT OF ADDITION OF PALM KERNEL SHELL ASH AND CRUMB RUBBER WASTE ON PHYSICAL AND MECHANICAL PROPERTIES OF GRIP RUBBER HANDS}

\author{
Eni Efendri ${ }^{1^{\star}}$, Epidia ${ }^{* \star}$, Dian Kharismadewi ${ }^{* \star}$, Hari Adi Prasetya ${ }^{\star \star \star}$ \\ *Mahasiswa Program Pasca Sarjana Teknik Kimia Universitas Muhammadiyah Palembang \\ **Pasca Sarjana Teknik Kimia Universitas Muhammadiyah Palembang \\ ***Baristand Industri Palembang \\ ${ }^{*}$ main contributor and coresponding author \\ ${ }^{*}$ e-mail : eni_effendri62@yahoo.co.id
}

Diterima: 22 April 2019; Direvisi: 25 April - 25 November 2019; Disetujui: 16 Desember 2019

\begin{abstract}
Abstrak
Industri karet remah (crumb rubber) menghasilkan limbah karet padat yang mengandung karet. Setiap pengolahan $100 \mathrm{~kg}$ karet Bokar menghasilkan limbah karet padat yang masih mengandung karet sekitar 3$5 \%$. Limbah padat ini ditumpuk di pabrik dan belum sepenuhnya diproses secara efektif. Limbah padat berupa cangkang sawit mengandung silika $\left(\mathrm{SiO}_{2}\right)$ yang cukup tinggi mencapai 50-56\%. Cangkang sawit selama ini dimanfaatkan sebagai bahan bakar boiler untuk menghasilkan energi mekanik dan panas pada penggilingan minyak kelapa sawit (CPO), menyisakan abu cangkang sawit yaitu sekitar $15 \%$ dari berat total cangkang sawitnya. Abu dari sisa pembakaran pada boiler berupa abu dibuang dekat pabrik sebagai limbah padat yang tidak dimanfaatkan. Limbah crumb rubber dan abu cangkang sawit ini dapat dikembangkan dengan membuat Vulkanisat dan Barang jadi Handgrip Rubber sepeda motor berbasis Styrene Butadiene. Pembuatan kompon vulkanisat Hand grip Rubber dengan menggunakan Lima perlakuan variasi abu cangkang sawit dan zeosil sebagai bahan pengisi sekaligus berfungsi sebagai penguat dengan 5 perlakuan dan 4 perlakuan variasi limbah padat Crumb rubber dan SBR dalam pembuatannya ada penambahan bahan kimia lainnya diperoleh hasil yang terbaik dengan menggunakan kompon formula 4 yaitu dengan penambahan Limbah Crumb Rubber 70 phr, SBR 30 phr dan Abu Cangkang Sawit 45 phr dengan Zeosil 15 phr serta dan pengujian secara visual. Formulasi Kompon 4 memenuhi persyaratan untuk pengujian fisik dan mekanik yaitu kekerasan yaitu 67,67 shore A dan pengujian Kekerasan After Aging sama yaitu 67,33 shore A; kekuatan tarik 71.59 $\mathrm{kg} / \mathrm{cm}^{2}$, setelah aging, Elongation at Break (Perpanjangan Putus), \% yaitu $388 \%$, after Aging yaitu $360 \%$. Untuk produk jadi hand grip rubber hasil dilakukan pengujian Visual dari 5 Panelis lebih menyukai Hand Grip rubber yang dibuat dari Formula K4. Formulasi kompon 4, modal tetap per bulan Rp 2.630.000,- dan total biaya variabel sebesar Rp 34.180.000,- per bulannya. Rp 25.200.000 kapasitas produksi per bulan, 30.000 kg, menghasilkan 201.000 buah Hand grip Rubber per bulan dan harga jual Rp 6.000,- BEP unit 974 unit Handgrip Rubber, waktu Pengembalian investasi 5,5 bulan.
\end{abstract}

Kata kunci : Bahan pengisi, Abu cangkang sawit, ziosil, limbah karet, crumb rubber, SBR, handle grip rubber.

\begin{abstract}
Crumb rubber industry produces solid rubber waste containing rubber. Each processing of $100 \mathrm{~kg}$ of rubber processing material (bokar) produces solid rubber waste that still contains about 3-5\% rubber. This solid waste is stacked in a factory and cannot be used effectively. Solid waste containing silica palm kernel shell $\left(\mathrm{SiO}_{2}\right)$ which is quite high reaches $50-56 \%$. Palm shells have been used as fuel for boilers to produce mechanical energy and heat in palm oil mills, leaving about $15 \%$ of the total weight of the palm shells. Ash from the combustion residue in the boiler consists of ash that is removed near the plant as solid waste that cannot be utilized. Waste of crumb rubber and palm kernel shell ash can be developed by making Vulcanisate and Finished Goods Rubber Motorcycle Handgrip based on Styrene Butadiene. Making volcanic compound Rubber Hand grip using variations of palm shell and zeosil ash as a filler material and reinforcing material. It uses 5 treatments and 4 variations of other treatment in solid waste Crumb rubber and SBR in its manufacture with the addition of certain chemicals. The best result of the treatment is using formula 4 compound, namely using Crumb Waste Rubber $70 \mathrm{Phr}$, SBR $30 \mathrm{Phr}$ and Palm Shell $45 \mathrm{Phr}$ with Zeosil $15 \mathrm{Phr}$. This is visually tested. The result of Physics testing are 67.67 shore $A$ and After Aging Violence test is 67.33 Shore A; tensile strength $71.59 \mathrm{Kg} / \mathrm{cm}^{2}$. After aging testing: Elongation at break (Elongation at Break), \% after aging $388 \%$, after Aging at $360 \%$.
\end{abstract}

Keywords : Fillers, palm shell ash, ziosil, rubber waste, crumb rubber, SBR, handle grip rubber. 


\section{PENDAHULUAN}

Industri karet remah (crumb rubber) menghasilkan limbah karet padat yang mengandung karet. Setiap pengolahan $100 \mathrm{~kg}$ karet Bokar menghasilkan limbah karet padat yang masih mengandung karet sekitar 3-5\%. Limbah padat ini ditumpuk dipabrik dan belum sepenuhnya diproses secara efektif. Limbah padat berupa cangkang sawit mengandung silika $\left(\mathrm{SiO}_{2}\right)$ yang cukup tinggi mencapai 50-56\%. Cangkang sawit selama ini dimanfaatkan sebagai bahan bakar boiler untuk menghasilkan energi mekanik dan panas pada penggilingan minyak kelapa sawit (CPO), menyisakan abu cangkang sawit (ACS) yaitu sekitar 15\% dari berat total cangkang sawitnya. Abu dari sisa pembakaran pada boiler berupa abu dibuang dekat pabrik sebagai limbah padat yang tidak dimanfaatkan.

Crumb rubber merupakan karet setengah jadi yang di buat dari karet Alam. Karet alam berasal dari tumbuhan Hevea brasiliensis, merupakan polimer alam dengan monomer isoprene. Polimer karet alam terdiri dari 97\% polimer cis-1,4-polyisoprene dengan rumus empiris $\left(\mathrm{C}_{5} \mathrm{H}_{8}\right)_{n}$ (Nasruddin, 2017). Karet alam terbentuk dari getah karet atau lateks kebun yang digumpalkan dan mengalami proses pengeringan. Karet alam tersusun dari hidrokarbon karet dan senyawa non-karet. Salah satu senyawa non-karet adalah protein. Senyawa nonkaret lain adalah karbohidrat, lipid, karoten, glikolipid, mineral, enzim, fosfolipid dan berbagai bahan lain. Karet merupakan bahan alam dan pada umumnya sebagai poliisoprena (polimer dari satuan sis-2, 2-isoprena) berupa getah (lateks) yang berasal dari pohon karetdengan komposisi kurang lebih 28\% karet, $60 \%$ air dan sisanya garam-garam anorganik, zat telur dan gula, dan damar, dimana semuanya adalah polimer dari isoprene (C5H8). (Arizal, R. 1994)

Crumb rubber merupakan produk karet yang relatif baru dalam perdagangan yang termasuk dalam kategori karet spesifikasi teknis. Proses pengolahan crumb rubber merupakan suatu proses pengolahan karet alam menjadi bandela melalui tahapantahapan proses yang telah ditentukan. Tahapan proses pengolahan crumb rubber dibagi menjadi 3 proses yaitu proses penimbangan, proses produksi basah, proses produksi kering (Safitri, 2010). Industri pengolahan karet di Sumatera Selatan diantaranya menghasilkan karet remah (crumb rubber - Standar Indonesian Rubber. Provinsi Sumatera Selatan merupakan salah satu penghasil karet terbesar $d$ ilndonesia dengan luas areal dan produksi perkebunan karet tahun 2017 yaitu $845.167 \mathrm{Ha}$ dan 970.678 ton diantaranya menghasilkan karet remah (crumb rubber - Standar Indonesian Rubber). Jenis karet remah mendominasi produksi industri karet dengan kapasitas olah mencapai 987 ribu ton $(98,7 \%)$ diperoleh dari 26 unit pabrik yang tersebar ditujuh kabupaten dan kota, sedangkan yang lainnya pabrik Sit Asap dan pabrik lateks pekat (Vachlepi, A., \& Suwardin, D., 2015). Karet remah yang dihasilkan di Ekspor dalam bentuk bahan mentah atau bahan setengah jadi yaitu crumb rubber. (Rahmaniar, 2017).

Penelitian lain pernah dilakukan dengan Pemanfaatan karet limbah industry crumb rubber sebagai substitusi karet SIR pada pembuatan suku cadang kendaraan bermotor. Prosiding Seminar Nasional Kulit, Karet dan Plastik ke 5 Yogyakarta, 2016 Daud dan Suharman (2016). Pengaruh Jumlah Bahan Pengisi sebagai bahan pembuatan pijakan kaki sepeda motor (foot step) Delvitasari, F., Maryanti dan Winarto (2017) dan memanfaatkan limbah industri crumb rubber (limbah padat crumb rubber masih mengandung karet) pembuatan Tegel Karet (2017) oleh Rahmaniar. Hasil penelitian menunjukkan bahwa limbah padat industri crumb rubber yang masih mengandung karet dapat dimanfaatkan kembali menjadi bahan baku pembuatan barang jadi karet pembuatan tegel karet.

Karet sintetis menurut Setyowati (1992), Styrene Butadiene Rubber dikenal sebagai SBR, yang merupakan synthetic rubber. SBR (Styrene Butadiene Rubber) merupakan kopolimer 
emulsi dari butadiene dan akrilonitril dengan perbandingan dari $55 \%$ berat butadiene 45 sampai $82 \%$ berat akrilonitril. Digunakan terutama untuk mendapatkan sifat ketahanan terhadap pembengkakan dalam minyak atau solven, pada penelitian ini digunakan sebagai campuran bahan baku limbah padat crumb rubber yang mengandung karet.

Dalam pembuatan barang jadi karet hand grip rubber pada penelitian ini digunakan juga bahan tambahan yang disebut bahan pengisi (filler) dari abu cangkang sawit (ACS). Di Indonesia potensi cangkang sawit sangat besar, cangkang sawit seperti halnya kayu diketahui mengandung komponenkomponen serat seperti selulosa, hemiselulosa, dan lignin. Menurut (Widiarsi, 2008) cangkang kelapa sawit mempunyai komposisi kandungan selulosa (26,27\%), hemiselulosa $(12,61 \%)$, dan lignin (42,96\%). Pada proses pengolahan kelapa sawit menjadi CPO, dari 1 ton TBS yang diolah dapat diperoleh CPO sebanyak 140-220 kg. Proses ini membutuhkan energi sebanyak 20-25 kWh/t dan 0.73 ton steam (uap panas). Limbah padat yang dihasilkan adalah serat dan cangkang sebanyak $190 \mathrm{~kg}$ dan $230 \mathrm{~kg}$ TKKS segar (kadar air 65\%). Cangkang sawit yang dimanfaatkan sebagian besar sebagai bahan bakar boiler PKS. Limbah padat berupa abu cangkang sawit biasanya dimanfaatkan untuk berbagai kebutuhan diantaranya sebagai pengeras jalan dan belum dimanfaatkan secara maksimal (Fauzi,Y, 2012). Berdasarkan data abu boiler PKS mengandung $\mathrm{SiO}_{2}, \mathrm{Al}_{2} \mathrm{O}_{3}, \mathrm{Fe}_{2} \mathrm{O}_{3}$, dan $\mathrm{CaO}$ dengan persentase kandungan berturut-turut $64,36 \%, 4,36 \%, 3,41 \%$, dan 7,92\%. Dari data diatas Abu boiler merupakan bahan material yang bersifat pozzolan, karena abu boiler yang dihasilkan di sisa pembakaran ini mempunyai kandungan silika yang cukup tinggi (Endriani, 2012). Dapat dilihat penelitian sebelumnya yang menggunakan silikat dari Yuniari, A., Any, S., dan Buchori, A. 2001. Optimalisasi Kondisi Proses Vulkanisasi terhadap Sifat Fisis Kompon Karet yang Menggunakan Bahan Pengisi Jenis Silikat. Prosiding Seminar Nasional Kimia. Surakarta.

Vulkanisat dengan komposisi karet, sulfur, akselerator, aktivator dan asam organik relatif bersifat lembut. Nilainya dalam industri modern pun relatif rendah. Untuk memperbaiki nilai di industri perlu ditambahkan bahan pengisi. Penambahan ini meningkatkan sifat-sifat mekanik seperti tensile strength, tear resistance, hardness dan abrasion resistance. Bahan yang ditambahkan disebut reinforcing fillers dan perbaikan yang ditimbulkan disebut reinforcement. Bahan yang baik untuk memperbaiki sifat karet tertentu, belum tentu bekerja sama baiknya untuk jenis karet lain. Peningkatan jumlah filler menyebabkan perbaikan sifat vulkanisat. Bahan pengisi yang aktif atau bahan pengisi penguat akan meningkatkan sifat mikanik diatas maka butir butir bahan pengisi harus merata didalam kompon Contoh bahan pengisi yang aktif yaitu Zeosil, Aluminium Silikat, Silika, Magnesium Silikat, dan Carbon Black. Bahan pengisi yang tidak aktif atau netral hanya akan menambah kekerasan dan kekakuan pada karet yang dihasilkan sedangkan kekuatan dan sifat lainnya akan menurun. Contoh bahan pengisi yang tidak aktif yaitu Kaolin, berbagai jenis tanah liat, Kalsium Karbonat, Magnesium Karbonat, Barium Sulfat, dan Barit (Hari Adi Prasetya dan Popy Marlina, 2018).

Penelitian bahan pengisi untuk produk karet alam, diantaranya karakteristik kompon karet dengan menggunakan bahan pengisi carbon Black (Sasongko, A.R, 2012) dengan variable penelitian ukuran partikel (N220, N330, N550 dan N660) dan jumlah phr $(30,40,50)$ carbon black dan hasil penelitian Partikel yang lebih kecil (N220) memberikan efek penguatan yang lebih besar pada kekuatan Tarik, abrasi dan kekerasan, dengan phr 30-40. penelitian Karet Alam (NR): StyreneButadiene Rubber (SBR) dengan bahan pengisi Silicon Oxide (Nuyah, 2009) dengan variable Rasio NR : SBR (dalam 
phr) $=100: 0,70: 30,50: 50,30: 70,0: 100$ hasil penelitian Kompon yang memenuhi SNI 06-7031-2004 adalah yang memiliki NR : SBR = 50:50. Penelitian Seal tabung gas berbahan karet alam yang dibuat dengan bahan pengisi pasir kuarsa sebagai pengganti karbon hitam dapat memenuhi persyaratan SNI 7655:2010 (Suharman dan Harun, 2017).

\section{BAHAN DAN METODE}

\section{Bahan dan Alat}

Bahan yang digunakan Limbah crumb rubber (NR/natural rubber), Styrene Butadiene Rubber (SBR), Arang abu cangkang kelapa sawit, Zeosil, Kaolin / Kalsium Karbonat ZnO, As. Stearat, Cumaron Resin, Minarek oil, Butylated hydroxytoluene (BHT), Mercaptodithio benzothiazol (MBTS), Sulfenamide (CBS), Polyethylene glycol (PEG), Trimethyl Quinon (TMQ), Tetramethyl tiuram disulfide (TMTD), Titan oksida, pewarna, sulfur.

Alat yang digunakan pada penelitian ini adalah gunting, Knipe, skop kecil, Kuwas, cetakan barang jadi karet (karet pegangaan atau Handle Grip), timbangan metlerp1210 kapasitas $1200 \mathrm{~g}$, timbangan duduk merek Berkel kapasitas $15 \mathrm{~kg}$, open mill L40 cm D18cm kapasitas $1 \mathrm{~kg}$, cutting scraf besar dan alat press, Tensile Strength tester, Aging Oven, Pnewmatic Punch Press Tester.

Rancangan penelitian yang dilakukan dalam skala laboratorium menggunakan metode Rancangan Acak Lengkap (RAL) non Faktorial. rancangan yang dilakukan pada Tabel 1 dan Tabel 2.

\section{Metode Penelitian}

- Penimbangan

Bahan yang diperlukan untuk masing-masing formulasi kompon ditimbang sesuai perlakuan. Jumlah dari setiap bahan di dalam formulasi kompon dinyatakan dalam phr (berat per seratus karet) di konversikan ke satuan Gram..

- Mixing (pencampuran)

Proses pencampuran dilakukan dalam gilingan terbuka (open mill), yang telah dibersihkan. Selanjutnya dilakukan proses yaitu Mastikasi karet alam dari limbah padat crumb rubber yang mengandung karet dan karet sintetis jenis SBR selama 1-3 menit dan tambahkan. Pencampuran polymer dengan bahan kimia untuk pembuatan kompon /vulkanisat karet antara lain Bahan penggiat/activator, ZnO dan asam stearat ditambahkan, dipotong setiap sisi satu sampai tiga kali selama 2-3 menit, Antioksi dipotong setiap sisi sampai 3 kali selama 2-3 menit, bahan pengisi bahan filler Abu cangkang sawit dan Zeosil ditambahkan, setiap sisi dipotong sampai dua atau tiga kali selama 3-8 menit. Pelunak (softener) minarek oil ditambahkan, setiap sisi dipotong sampai dua atau tiga kali selama 3-8 menit. Accelerator MBTS dan CBS ditambahkan, setiap sisi dipotong dua atau tiga kali selama 1-3 menit. Vulkanisator sulfur ditambahkan sampai homogen dan Vulkanisat dikeluarkan dari open mill dan ditentukan ukuran ketebalan lembaran kompon dengan menyetel jarak roll pada cetakan sheet, dikeluarkan dan diletakkan diatas plastik transfaran dan kompon dipotong disesuaikan dengan barang jadi yang akan dibuat dan dilakukan pengujian. Pencetakan vulkanisat.

\section{Peubah yang diamati}

Peubah yang diamati dalam penelitian ini meliputi parameter kekerasan, kekuatan tarik perpanjangan putus, kekerasan sebelum dan sesudah Aging.

Tabel 1. Variasi penambahan Cangkang Sawit dan Zeosil

\begin{tabular}{llllll}
\hline ACS & 60 & 45 & 30 & 15 & 0 \\
Z & 0 & 15 & 30 & 45 & 60 \\
LCR & 70 & 70 & 70 & 70 & 70 \\
SBR & 30 & 30 & 30 & 30 & 30 \\
\hline \multicolumn{1}{l}{ Keterangan : } & ACS : Bubuk Cangkang Sawit \\
& & Z : Zeosil \\
& LCR : Limbah Crumb Rubber \\
& SBR : Styrene Butadiene.
\end{tabular}


Tabel 2. Variasi Perubahan Limbah Crumb Rubber dan SBR

\begin{tabular}{ccccc}
\hline BCS & 15 & 15 & 15 & 15 \\
Z & 45 & 45 & 45 & 45 \\
LCR & 100 & 90 & 80 & 70 \\
SBR & 0 & 10 & 20 & 30 \\
\hline Keterangan : & ACS : Bubuk Cangkang Sawit \\
& Z $:$ Zeosil \\
& LCR : Limbah Crumb Rubber \\
& SBR : Styrene Butadiene.
\end{tabular}

\section{HASIL DAN PEMBAHASAN}

\section{Pengaruh Penambahan Abu Cangkang Sawit dan Zeosil Pada Kekerasan}

Pengujian kekerasan (hardness) bertujuan untuk mengetahui besarnya kekerasan vulkanisat karet dengan kekuatan penekanan tertentu. Kekerasan vulkanisasi karet merupakan besarnya pergerakan jarum skala penunjuk ukuran, akibat besarnya tekanan balik dari vulkanisat karet terhadap jarum penekan melalui suatu mekanisme alat dihubungkan dengan pegas yang akan mengerakkan jarum penunjuk ukuran kekerasan (Adi Cipriadi, 2013) Nilai kekerasan (hardness/
ShoreA) dari kompon karet diperoleh dari hasil uji kekerasan (ShoreA). Kekerasan merupakan ukuran resistensi bahan terhadap deformasi plastis lokal, dimana semakin kaku dan keras maka kekerasan (shore A) akan tinggi (Susanto dan Daud, 2017).

Berdasarkan hasil pengujian kekerasan kompon Handgrip Rubber yang dihasilkan dari 5 (Lima) perlakuan dengan 3 (Tiga) kali pengulangan tidak berpengaruh signifikan tidak jauh berbeda yaitu berada pada range 6568,66 Shore A dan hasil pengujian kekerasan setelah pengusangan (aging) dengan temperature 70 selama 24 Jam pada range 64.66-68. Hasil pengujian parameter kekerasan kompon Handgrip Rubber dapat dilihat dari 5 (lima) kali perlakuan dengan 3 (Tiga) kali pengulangan terlihat pada perbandingan antara setiap perlakuan hasil pengujian kekerasan kompon sebelum dan sesudah pengusangan semuanya masih masuk pada persyaratan Handgrip Rubber dapat dilihat pada Gambar 1.

Tabel 3. Karakteristik Rata-Rata Fisik Vulkanisat Handgrip Rubber Variasi Abu Cangkang Sawit : Zeosil

\begin{tabular}{|c|c|c|c|c|c|c|}
\hline \multirow{2}{*}{ No. } & \multirow{2}{*}{ Parameter } & \multicolumn{5}{|c|}{ Kompon (rata-rata) } \\
\hline & & K1 & K2 & K3 & K4 & K5 \\
\hline 1 & Kekerasan Shore A & 65.67 & 65.33 & 67.33 & 67.67 & 68.66 \\
\hline 2 & $\begin{array}{l}\text { Kekuatan Tarik N/mm } \\
\text { SNI ISO } 37: 2015\end{array}$ & 6.15 & 6.49 & 6.76 & 7.04 & 9.69 \\
\hline 3 & $\begin{array}{l}\text { Perpanjangan Putus \% } \\
\text { SNI ISO 37:2015 }\end{array}$ & 310 & 360 & 381,67 & 388 & 395 \\
\hline \multicolumn{7}{|c|}{ Setelah Aging $\left(70^{\circ} \mathrm{C}, 24 \mathrm{Jam}\right)$} \\
\hline 1 & Kekerasan Shore A & 65,33 & 64,66 & 66,33 & 67,33 & 64,33 \\
\hline 2 & $\begin{array}{l}\text { Kekuatan Tarik Setelah } \mathrm{N} / \mathrm{mm}^{2} \\
\text { SNI ISO 37:2015 dan } \\
\text { SNI ISO 188:2015 }\end{array}$ & 6.14 & 6.32 & 6.49 & 6.84 & 9,43 \\
\hline 3 & $\begin{array}{l}\text { Perpanjangan Putus \% } \\
\text { SNI ISO 37:2015 }\end{array}$ & 268 & 345 & 260 & 360 & 385 \\
\hline
\end{tabular}


Tabel 4. Karakteristik Rata-Rata Fisik Vulkanisat Handgrip Rubber Variasi Crumb Rubber : SBR

\begin{tabular}{|c|c|c|c|c|c|}
\hline \multirow[b]{2}{*}{ No. } & \multirow{2}{*}{ Parameter } & \multicolumn{4}{|c|}{ Kompon (rata-rata) } \\
\hline & & K1 & $\mathrm{K} 2$ & $\mathrm{~K} 3$ & K4 \\
\hline 1 & Kekerasan Shore A & 57 & 61.66 & 63 & 67.67 \\
\hline 2 & $\begin{array}{l}\text { Kekuatan Tarik N/mm² } \\
\text { SNI ISO } 37: 2015\end{array}$ & 5.83 & 6.27 & 6.47 & 7.04 \\
\hline 3 & $\begin{array}{l}\text { Perpanjangan Putus \% } \\
\text { SNI ISO 37:2015 }\end{array}$ & 217 & 239 & 270 & 388 \\
\hline \multicolumn{6}{|c|}{ Setelah Aging $\left(70^{\circ} \mathrm{C}, 24 \mathrm{Jam}\right)$} \\
\hline 1 & Kekerasan Shore A & 52 & 59.6 & 57.66 & 67.33 \\
\hline 2 & $\begin{array}{l}\text { Kekuatan Tarik Setelah N/mm² } \\
\text { SNI ISO 37:2015 dan } \\
\text { SNI ISO 188:2015 }\end{array}$ & 4.96 & 6.21 & 6.21 & 6.84 \\
\hline 3 & $\begin{array}{l}\text { Perpanjangan Putus \% } \\
\text { SNI ISO 37:2015 dan } \\
\text { SNI ISO 188:2015 }\end{array}$ & 198.3 & 202 & 247.33 & 360 \\
\hline
\end{tabular}

Berdasarkan Gambar 1 hasil kekerasan kompon tertinggi pada kompon 4 yaitu variasi penggunaan bahan pengisi abu cangkang sawit hasil pemanasan mesin Boiler yaitu 67.67 dan hasil setelah aging 67.33, hasil setelah aging temperature $70^{\circ} \mathrm{C}$ selama 24 jam, tidak sampai berpengaruh pada penurunan sifat kekerasannya. Namun kommpon 4 masih dibawah kekerasan kompon 5 tanpa Abu cangkang sawit dengan nilai kekerasan 68.66 Shore A, dan setelah Aging $70^{\circ} \mathrm{C}, 24$ jam. Kekerasan terendah pada perlakuaan kompon 2 dan Kompon 5 yaitu 65.33 Shore A. Hasil terendah setelah aging diperoleh pada perlakuan K5 yaitu 64.33 Shore A. Dengan demikian penggunaan Limbah crumb Rubber dan abu cangkang sawit tidak berpengaruh signifikan terhadap perubahan kekerasan kompon yang dihasilkan.

Hasil uji ini menunjukkan bahwa dari kelima perlakuan untuk kompon
Handgrip Rubber yang dihasilkan sesuai dengan porsi kegunaannya dengan standar ASTM D 2240 kompon terbaik dari uji hardness adalah kompon $\mathrm{K} 4$ yaitu sebelum pengusangan 67.66 Shore A dan setelah pengusangan 67.33, namun semua kompon 1, kompon 2, kompon 3, kompon 4 dan kompon 5 semuanya memenuhi persyaratan mutu SNI 06-7031-2004 Handgrip Rubber yaitu $70+5$ Shore $A$ dan pengurangan setelah aging 10\%. Dengan demikian perlakuaan pengujian tidak berpengaruh signifikan terhadap perubahan kekerasan kompon yang dihasilkan baik sebelum pengusangan maupun setelah pengusangan $\mathrm{Hal}$ ini merupakan indikasi bahwa unsur silika yang terkandung dalam abu cangkang sawit mampu mempengaruhi pada densitas ikatan silang yang ada dalam metrik polimer karet alam. 


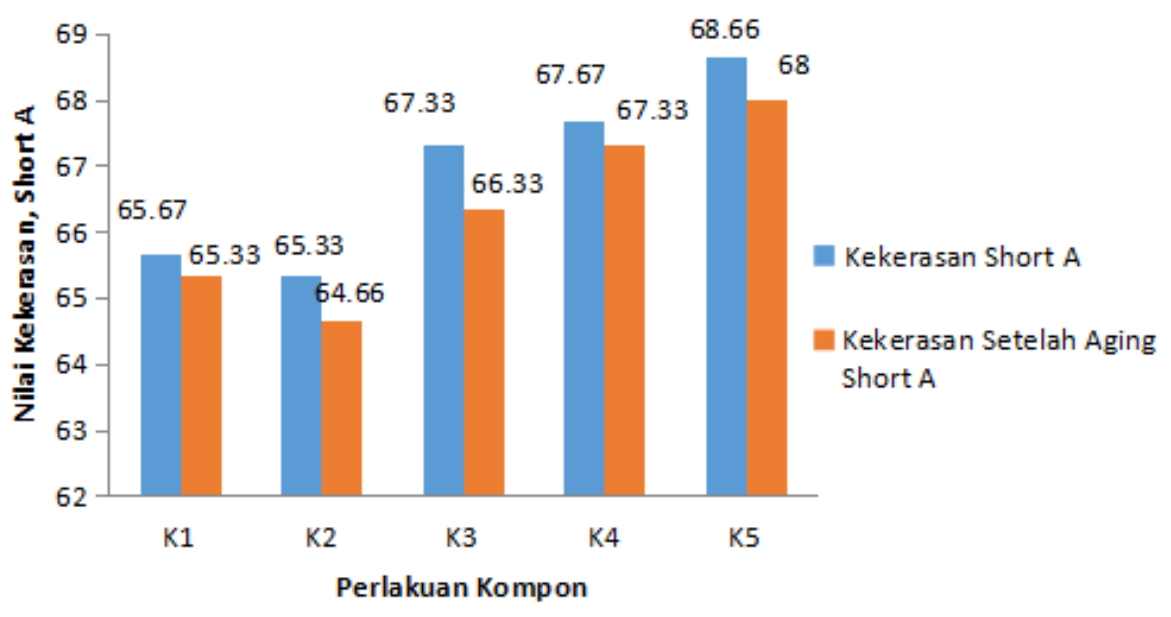

Gambar 1. Hasil Pengujian Hardness (Kekerasan) pada Pembuatan Kompon Handgrip Rubber

\section{Pengaruh Penambahan Abu Cangkang Sawit dan Zeosil pada Kekuatan Tarik \\ Kekuatan tarik merupakan} pengujian fisika karet yang terpenting dan paling sering dilakukan. Dengan pengujian ini pula dapat diketahui besar yang dibutuhkan untuk meregangkan vulkanisat karet hingga putus. Kekuatan tarik adalah besar beban yang diperlukan untuk meregangkan potongan uji hingga putus yang dinyatakan dengan berat $\mathrm{N} / \mathrm{mm}^{2}$ luas penampang potongan uji sebelum diregangkan. Dengan pengujian ini dapat ditetapkan waktu vulkanisasi optimum suatu kompon dan pengaruh pengusangan pada suatu vulkanisasi, selain itu juga pengujian ini menggambarkan kekuatan dan kekenyalan karet (Prasetya, 2012). Pengujian kompon karet untuk 5 (lima) perlakuan semuanya memenuhi persyaratan kompon karet pegangan setang (Handgrip Rubber) dalam SNI 06$7031-2004$, yaitu minimal $70 \mathrm{~kg} / \mathrm{cm}^{2}$. Nilai tegangan putus yang semakin besar menunjukkan bahwa karet komponen Handgrip Rubber semakin elastis. Hasil pengujian Kekuatan tarik kompon Handgrip Rubber sebelum pengusangan dari lima perlakuan dan tiga kali pengulangan dapat dilihat pada Gambar 2. Gambar 2 menunjukkan pengaruh penggunaan Abu cangkang sawit sebagai bahan pengisi pada pembuatan kompon karet. Menggunakan limbah pada industri crumb rubber.Nilai kekuatan tarik yang dihasilkan dari perlakuan K1, K2, K3 dan perlakuan K4. Berdasarkan hasil pengujian ternyata Kekuatan tarik kompon Handgrip rubber yang dihasilkan dari bahan baku limbah karet hasil industri crumb rubber dan bahan pengisi abu cangkang sawit sebelum pengusangan menghasilkan nilai Kekuatan tarik rata-rata terendah $62.54 \mathrm{Kg} / \mathrm{Cm}^{2}$ dan nilai kekerasan ratarata tertinggi $69.56 \mathrm{Kg} / \mathrm{Cm}^{2}$ dan setelah pengusangan rata rata nilai terendah $64.27 \mathrm{Kg} / \mathrm{Cm}^{2}$ dan nilai rata rata tertinggi $66.51 \mathrm{Kg} / \mathrm{Cm}^{2}$, lebih rendah dari $\mathrm{K} 5$ $98.61 \mathrm{Kg} / \mathrm{Cm}^{2}$ dan nilai setelah aging $95.9 \mathrm{Kg} / \mathrm{Cm}^{2}$ dapat dilihat pada Gambar 2. 


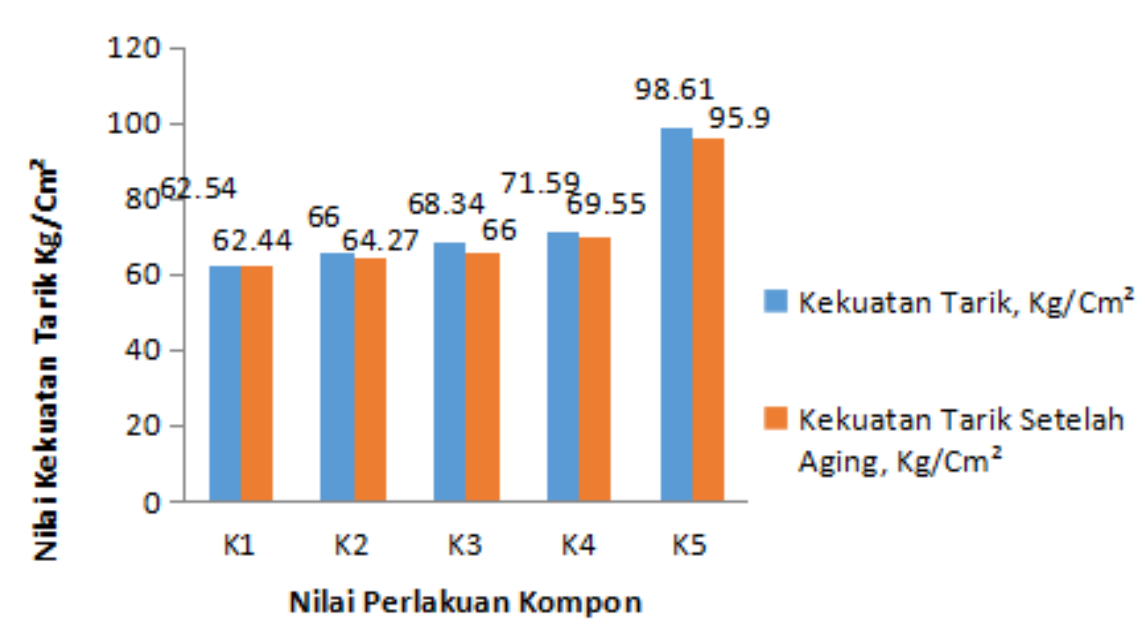

Gambar 2. Hasil Pengujian Kekuatan Tarik dalam Pembuatan Kompon Handle Grip

Gambar 2 menunjukkan hasil pengujian Kekuatan tarik yang naik dengan kata lain stabil. Tegangan putus terbesar terdapat pada formula K4 yaitu $71.59 \mathrm{~kg} / \mathrm{cm}^{2}$, setelah pengusangan $70^{\circ} \mathrm{C}, 24 \mathrm{Jam} 69.55 \mathrm{~kg} / \mathrm{cm}^{2}$ tapi masih dibawah yang cukup jauh berada dibawah Kompon 5 tanpa abu cangkang sawit dengan kekuatan tariknya yaitu $98.61 \mathrm{~kg} / \mathrm{cm}^{2}$, setelah pengusangan temperature $70^{\circ} \mathrm{C}$, selama 24 jam adalah $95.9 \mathrm{~kg} / \mathrm{cm}^{2}$. Kekuatan tarik dari semua perlakuan kompon memenuhi persyaratan kompon karet pegangan setang dalam SNI 06-7031-2004 adalah kompon 4 dan kompon 5, perlakuan kompon 1, kompon 2, kompon 3 tidak memenuhi persyaratan kekuatan tarik yang minimal $70 \mathrm{~kg} / \mathrm{cm}^{2}$ tetapi untuk persyaratan setelah pengusangan semua perlakuan masuk persyaratan. Kompon terbaik dari 4 perlakuan dan 3 pengulangan yang menggunakan abu cangkang sawit adalah kompon Handgrip Rubber pada perlakuan K4 yaitu $71.59 \mathrm{~kg} / \mathrm{cm}^{2}$. Hal ini merupakan indikasi bahwa unsur silika yang terkandung dalam abu cangkang sawit mampu mempengaruhi pada densitas ikatan silang yang ada dalam metrik polimer karet alam.

\section{Pengaruh Penambahan Abu Cangkang Sawit dan Zeosil pada Perpanjangan putus}

Perpanjangan putus adalah pertambahan panjang suatu potongan uji bila diregangkan sampai putus, dinyatakan dengan persentase dari panjang potongan uji sebelum diregangkan. Pengujian perpanjangan putus (elongation at break) bertujuan untuk mengetahui sifat-sifat tegangan dan regangan dari karet vulkanisat dan thermoplastik dan termasuk penentuan yield point melalui kekuatan dan pertambahan panjang vulkanisat karet ketika mengalami penarikan sampai perpanjangan tertentu dan sampai putus. Bila kemuluran terlalu besar, maka produk akan mudah ditarik sehingga pemakaian produk tidak dapat dikencangkan dengan cepat.

Nilai perpanjangan putus dari kompon karet diperoleh dari hasil uji perpanjangan putus. Perpanjangan putus merupakan pertambahan panjang suatu potongan uji kompon karet bila diregangkan sampai putus, dinyatakan dengan persentase dari panjang potongan uji sebelum diregangkan. Nilai perpanjangan putus yang semakin besar menunjukkan bahwa karet komponen Handle Grip semakin elastis. Dari gambar 3, terlihat bahwa hasil pengujian perpanjangan putus kompon Handgrip Rubber sebelum aging dari lima perlakuan dan tiga kali, dapat dilihat pada Gambar 3. 


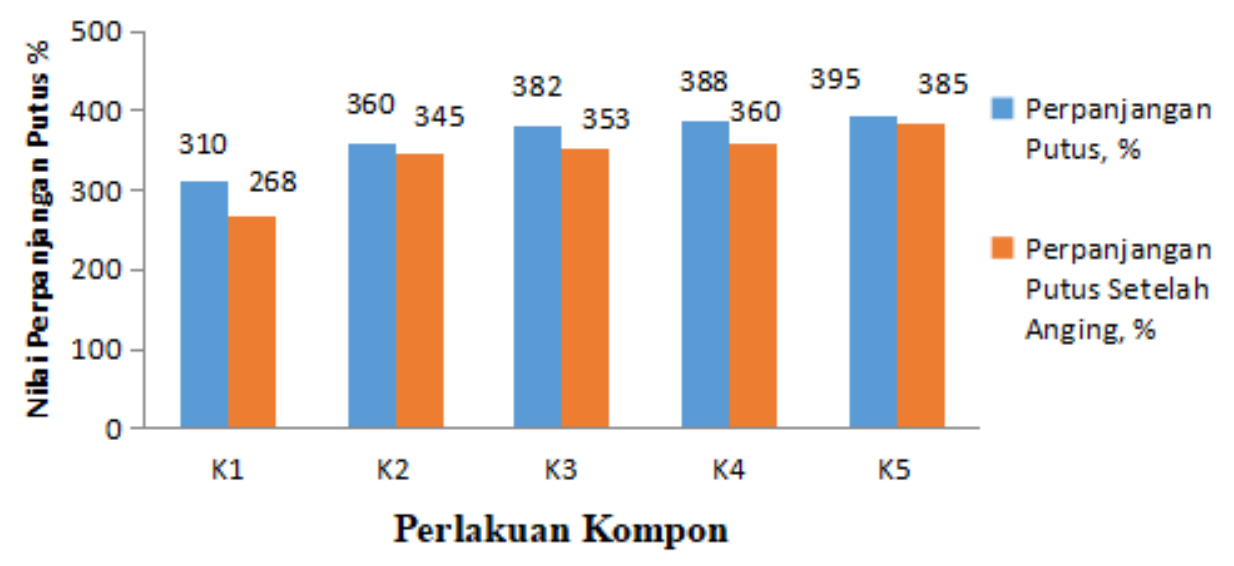

Gambar 3. Hasil Pengujian perpanjangan putus (Elongation at Break, \%) dalam Pembuatan Kompon Handgrip Rubber

Nilai perpanjangan putus dari kompon karet diperolehdari hasil uji perpanjangan putus Perpanjangan putus merupakan pertambahan panjang suatu potongan uji kompon karet bila diregangkan sampai putus, dinyatakan dengan persentase dari panjang potongan uji sebelum diregangkan. Nilai perpanjangan putus yang semakin besar menunjukkan bahwa karet komponen Handle Grip semakin elastis.

Pada Gambar 3, rata-rata hasil uji berkisar diantara $310-395 \%$ yang berarti semuanya hampir rata-rata diatas standar kompon walaupun antar perlakuan Kompon 1 dan sampai ke kompon 4 perpanjangan putusnya semuanya memenuhi standard yang telah dipersyaratkan. Perlakuan terendah terdapat pada perlakuan K1 yaitu $310 \%$, setelah Aging $70^{\circ} \mathrm{C}, 24$ Jam $268 \%$ dan perlakuan tertinggi menggunakan abu cangkang sawit adalah terdapat pada perlakuan K4 yaitu $388 \%$. Hal ini menunjukkan bahwa semua perlakuan dapat digunakan untuk pembuatan kompon Handgrip Rubber, untuk perlakuan terbaik pada penelitian ini adalah perlakuan pada K4 yaitu $338 \%$, walaupun masih dibawah kompon 5 tanpa abu cangkang sawit. Semua perlakuan kompon memiliki nilai perpanjangan putus menurun yang cukup signifikan, tetapi masih diatas rata rata persyaratan kompon handgrip Rubber.

\section{Pengaruh Penambahan Limbah Crumb Rubber dan SBR pada Kekerasan}

Hasil pengujian kekerasan kompon Handgrip Rubber yang dihasilkan dari 4 (Empat) perlakuan dengan 3 (tiga) kali pengulangan tidak berpengaruh signifikan jauh berbeda yaitu berada pada range 57-67,67 Shore A dan hasil pengujian kekerasan setelah pengusangan (aging) dengan temperature 70 selama 24 Jam pada range 52-67.33. Hasil pengujian parameter kekerasan kompon Handgrip Rubber dapat dilihat dari 4 (empat) kali perlakuan dengan 3 (Tiga) kali pengulangan terlihat pada perbandingan antara setiap perlakuan hasil pengujian kekerasan kompon sebelum dan sesudah pengusangan semuanya masih masuk pada persyaratan handle grip, kecuali pada kompon 1. Data hasil pengujian dapat dilihat pada gambar 5 . Pengusangan mengakibatkan turunnya sifat fisik barang karet seperti kekuatan tarik, perpanjangan putus, dan kekerasan selama masa penyimpanan. Karet menjadi keras dan retak, lunak dan lengket. Penurunan sifat fisik disebabkan terjadinya degradasi karet karena oksidasi oleh oksigen dan ozon. Oksidasi dipercepat dengan adanya panas, sinar ultraviolet, dan logam-logam yang mengkatalisa oksidasi karet. 


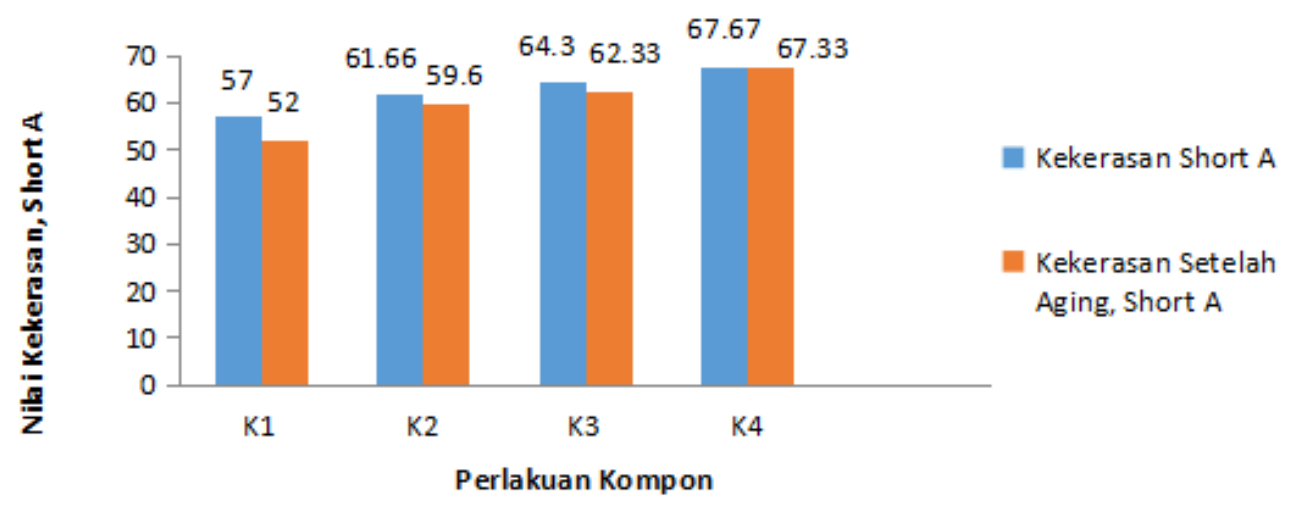

Gambar 4. Hasil Pengujian Hardness (Kekerasan) pada Pembuatan Kompon Handgrip Rubber

Berdasarkan Gambar 5 hasil kekerasan kompon tertinggi pada kompon 4 yaitu variasi penggunaan bahan pengisi abu cangkang sawit dari pembakaran pada mesin Boiler yaitu 67.67 dan hasil setelah aging 67.33, hasil setelah aging temperature $70^{\circ} \mathrm{C}$ selama 24 jam, tidak sampai berpengaruh pada penurunan sifat kekerasannya. Kekerasan terendah pada perlakuaan kompon 1 yaitu 57 Shore A, setelah Aging $70^{\circ} \mathrm{C}$ selama 24 Jam 52 Shore A. Dengan demikian penggunaan Limbah crumb Rubber dan SBR berpengaruh signifikan terhadap perubahan kekerasan kompon yang dihasilkan. Hasil uji ini menunjukkan bahwa dari keempat perlakuan untuk kompon Handle grip yang dihasilkan sesuai dengan porsi kegunaannya dengan standar ASTM D 2240. Kompon terbaik dari uji hardness adalah kompon
K4 yaitu sebelum pengusangan 67.66 Shore A dan setelah pengusangan 67.33, tetapi kompon 1 s.d kompon 3 tidak memenuhi persyaratan mutu SNI 06-7031-2004 Handgrip Rubber yaitu $70+5$ Shore A dan pengurangan setelah aging $10 \%$. Dengan demikian perlakuan pengujian berpengaruh signifikan terhadap perubahan kekerasan kompon yang dihasilkan baik sebelum pengusangan maupun setelah pengusangan.

\section{Pengaruh Penambahan Limbah Crumb Rubber dan SBR pada Kekuatan Tarik}

Hasil pengujian Kekuatan tarik kompon Handgrip Rubber sebelum dan sesudah pengusangan dari empat perlakuan dan tiga kali pengulangan dapat dilihat pada Gambar 5.

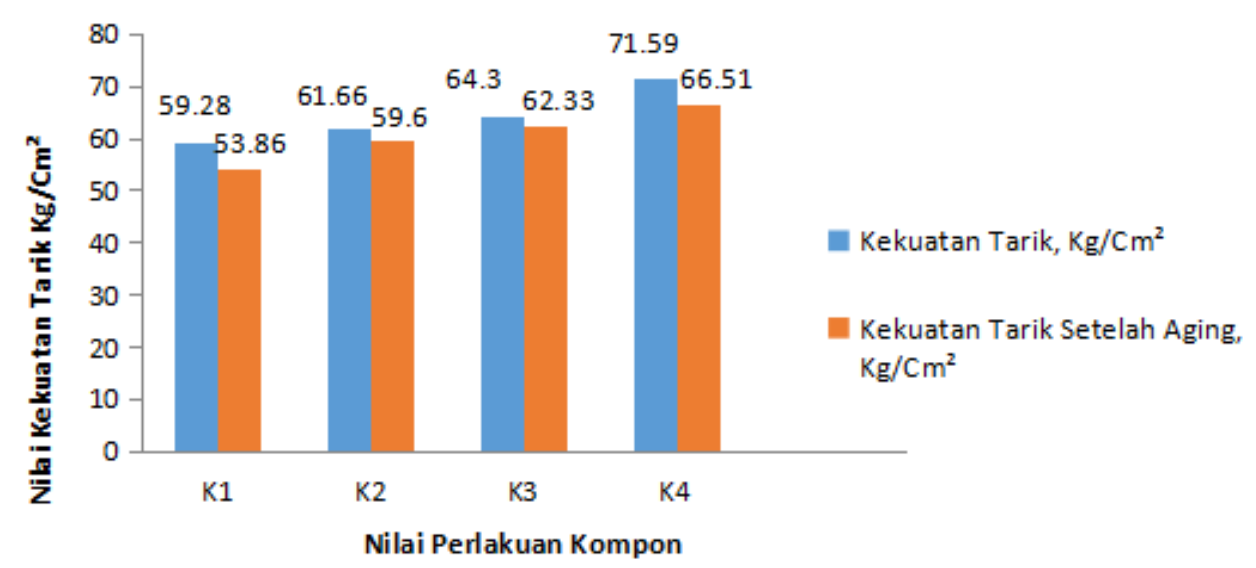

Gambar 5. Hasil Pengujian Kekuatan tarik Pembuatan Kompon Handgrip Rubber 
Gambar 5 menunjukkan hasil pengujian Kekuatan tarik yang turun naik dengan kata lain ketidakstabilan. Tegangan putus terbesar terdapat pada formula K4 yaitu $71.59 \mathrm{~kg} / \mathrm{cm}^{2}$ dan setelah pengusangan dengan temperatur $70^{\circ} \mathrm{C}$ selama 24 jam yaitu $66.51 \mathrm{~kg} / \mathrm{cm}^{2}$ memenuhi persyaratan kompon karet pegangan setang dalam SNI 06-7031-2004, yaitu minimal 70 $\mathrm{kg} / \mathrm{cm}^{2}$ dan persyaratan kompon Handgrip Rubber setelah pengusangan $55 \mathrm{~kg} / \mathrm{cm}^{2}$. Nilai kekuatan tarik terkecil adalah pada formula K1 yaitu 59.28 $\mathrm{kg} / \mathrm{cm}^{2}$. Perlakuan kompon 1, kompon 2, kompon 3 tidak memenuhi persyaratan kekuatan tarik yang minimal $70 \mathrm{~kg} / \mathrm{cm}^{2}$ tetapi untuk persyaratan setelah pengusangan semua perlakuan masuk persyaratan kecuali kompon 1. Kompon terbaik dari 4 perlakuaan dan 3 pengulangan adalah kompon Handgrip
Rubber pada perlakuan K4 yaitu 71.59 $\mathrm{kg} / \mathrm{cm}^{2}$.

\section{Pengaruh Penambahan Limbah Crumb Rubber dan SBR pada Perpanjangan Putus}

Perpanjangan putus merupakan pertambahan panjang suatu potongan uji kompon karet bila diregangkan sampai putus, dinyatakan dengan persentase dari panjang potongan uji sebelum diregangkan. Nilai perpanjangan putus yang semakin besar menunjukkan bahwa karet komponen Handgrip Rubber semakin elastis. Dari gambar 7, terlihat bahwa hasil pengujian perpanjangan putus kompon Handgrip Rubber sebelum aging dari lima perlakuan dan tiga kali, dapat dilihat pada Gambar 6.

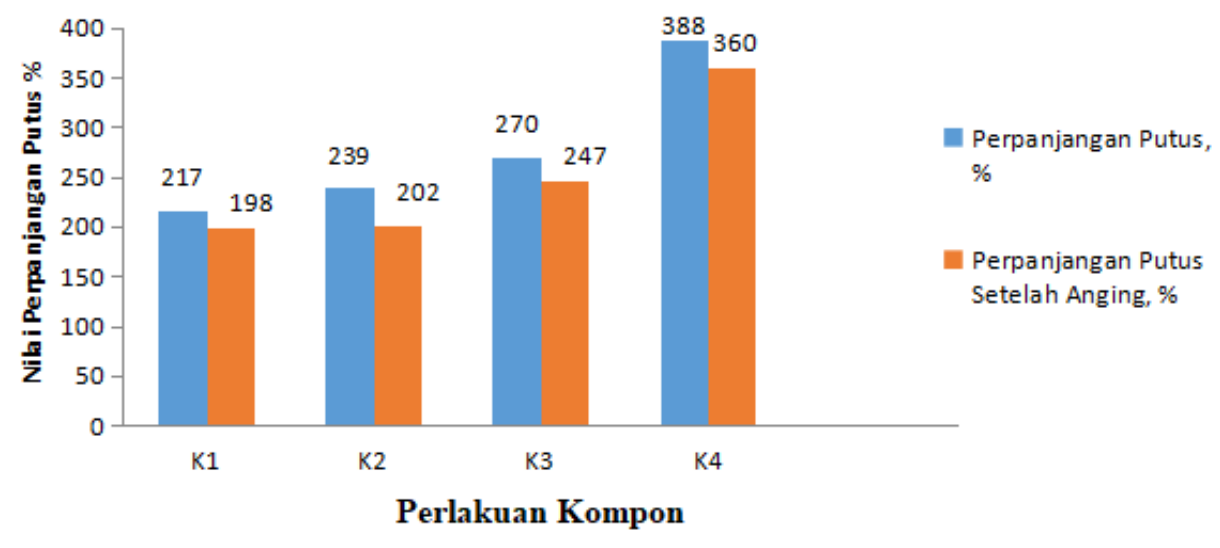

Gambar 6. Hasil Pengujian perpanjangan putus (Elongation at Break, \%) dalam Pembuatan Kompon Handle Grip

Pada gambar 6 , rata-rata hasil uji berkisar diantara $217 \%-388 \%$ yang berarti semuanya hampir rata-rata diatas standar kompon perlakuan Kompon 1 dan sampai ke kompon 4 perpanjangan putusnya naik terus dan perlakuan tertinggi terdapat pada perlakuan $\mathrm{K} 4$ yaitu $388 \%$. Hal ini menunjukkan bahwa semua perlakuan dapat digunakan untuk pembuatan kompon Handgrip Rubber, untuk perlakuan terbaik pada penelitian ini adalah perlakuan pada K4 yaitu $388 \%$. Semua perlakuan kompon memiliki nilai perpanjangan putus menurun yang cukup lumayan, tetapi masih diatas rata rata persyaratan kompon Handgrip Rubber.

\section{KESIMPULAN}

Paket teknologi pembuatan Handgrip Rubber memanfaatkan limbah padat crumb rubber yang masih mengandung karet dan abu cangkang sawit dari pembakaran mesin Boiler telah tersedia dengan keunggulan dapat terbuat dari kompon karet padat dan dapat dicampur dengan karet sintetis 
jenis SBR, disamping ketebalan dan ukuran dapat disesuaikan.

Pembuatan kompon Handgrip Rubber dengan menggunakan lima perlakuan variasi abu cangkang sawit dan Zeosil sebagai bahan pengisi sekaligus berfungsi sebagai penguat dengan 5 perlakuan dan 4 perlakuan variasi limbah padat Crumb rubber dan SBR dalam pembuatannya ada penambahan bahan kimia lainnya diperoleh hasil yang terbaik dengan menggunakan kompon formula 4 yaitu dengan penambahan Crumb Rubber 70 phr, SBR 30 phr dan Abu Cangkang Sawit 45 phr dengan Zeosil 15 phr serta dan pengujian secara visual.

Formulasi Kompon 4 memenuhi persyaratan untuk pengujian Fisika yaitu kekerasan yaitu 67,67 shore A dan pengujian Kekerasan After Aging sama yaitu 67,33 shore A; kekuatan tarik 71.59 $\mathrm{kg} / \mathrm{cm}^{2}$, setelah aging, Elongation at Break (Perpanjangan Putus), \% yaitu $388 \%$, after Aging yaitu 360\%.

\section{UCAPAN TERIMA KASIH}

Penulis menyampaikan terima kasih kepada Kepala Baristand Industri Palembang, Dekan Fakultas Teknik Universitas Muhamadiyah Palembang rekan-rekan tim riset, dewan redaksi, mitra bestari dan redaksi pelaksana atas terlaksananya penelitian dan terbitnya tulisan ini.

\section{DAFTAR PUSTAKA}

Alam, P. N. dan Rihayat, T., Sintesa dan Karakteristik Sifat Mekanik Karet Nanokomposit, Jurnal Rekayasa dan Lingkungan, 6(1):1-6, 2007.

Arizal, R. 1994. Pengetahuan dasar Elastomer. Kursus Teknologi Barang Jadi Karet. Balai Penelitian dan Teknologi Karet. Bogor.

Basseri, A. 2005. Theori Praktek Barang Jadi Karet. Balai Penelitian dan Teknologi Karet. Bogor.

Daud, D. dan Suharman (2016). Pemanfaatan karet limbah industry crumb rubber sebagai substutusi karet SIR pada pembuatan suku cadang kendaraan bermotor. Prosiding
Seminar Nasional Kulit, Karet dan Plastik ke5 Yogyakarta, 2016

Delvitasari, F., Maryanti dan Winarto, Pengaruh Jumlah Bahan Pengisi terhadap Kekerasan Kompon Foot step Sepeda Motor, Prosiding Semnas Pengembangan Teknologi Pertanian Politeknik Negeri Lampung, 2017.

Endriani, D. 2012. Pengaruh Penambahan Abu Cangkang Sawit Terhadap Daya Dukung dan Kuat Tekan pada Tanah Lempung Ditinjau dari Uji UCT dan CBR Laboaratorium. Tesis Program Pasca Sarjana Fakultas Teknik. Medan: Universitas Sumatera Utara.

Fachry, A. R., Sari, T. I., Putra, B. A., dan Kristianto, D. A., Pengaruh Penambahan Filler Kaolin terhadap Elastisitas dan Kekerasan Produk Souvenir dari Karet Alam (Hevea Brasiliensis, Prosiding SNTK TOPI, 2012.

Fachry, A. R., Sari, T. I., Sthevanie, Susanti, S., Pengaruh Filler Campuran Silika dan Kulit Kerang Darah terhadap Sifat Mekanis Kompon Sol Sepatu dari Karet Alam, Jurnal Teknik Kimia, 20 (3): 1-11, 2014.

Fauzi, Y. 2012. Kelapa Sawit, Budi Daya Pemanfaatan Hasil Limbah dan Limbah

Hari Adi Prasetya, Popy Marlina 2017, Penggunaan Bahan Pengisi Berbasis Sumber Daya Terbarukan, Universitas Sriwijaya

Hildayati, Triwikantoro, Faisal, H., dan Sudirman, Sintesa dan Karakterisasi Bahan Komposit Karet Alam-Silika, Prosiding Semnas Pascasarjana IXITS, 2009.

Honggokusumo, S. 1994. Kimia dan Teknologi Vulkanisasi. Kursus teknologi barang jadi karet. Balai Penelitian dan Teknologi Karet. Bogor.

Marlina, P., Pratama, F., Hamzah, B., dan Pambayun, R., Karakteristik Kompon Karet dengan Pengisi Arang Aktif Tempurung Kelapa dan Nano Silika Sekam Padi, Jurnal Teknologi Industri Pertanian, 25(1):85-93, 2015.

Nasruddin, Pengembangan Karet Alam dengan Bahan Pengisi dan Bahan Pelunak menjadi Tube Collar, Prosiding Semnas Kulit, Karet dan Plastik ke-6, 2017.

Nuyah, Penentuan Formulasi Karet Pegangan Setang (Grip Handle) dengan Menggunakan Karet Alam dan Karet Sintetis berdasarkan SNI 067031-2004, Baristand, 2009. 
Setyawati, P. 1992. Karet Sintetis Dalam Industri Barang Karet. Balai Penelitian dan Teknologi Karet. Bogor

Setyowati, Penny, DKK. 2008. Karet untuk komponen otomotif. Balai Besar Kulit, Karet dan Plastik, Yogyakarta.

Sayekti, T. dan Luciawati S. 1992. Teknologi Pembuatan Barang Karet Secara Umum. Balai Penelitian dan Teknologi Karet. Bogor.

Sasongko, A.R., Studi Pengaruh Ukuran Partikel dan Jumlah phr Carbon Black sebagai Bahan Pengisi terhadap Sifat Mekanik Produk Karet Alam, FMIPAUI, 2012

Suwardin. 2015. Penggunaan Garam Amonium dalam Produksi Karet Viscositas rendah dari Lateks

Thomas. J. 2005. Pengujian sifat fisika. Balai Penelitian dan Teknologi Karet. Bogor.

Rahmaniar. 2017. Pemanfaatan Limbah Padat Crumb Rubber Untuk
Pembuatan Tegel Karet Menggunakan Bahan Pengisi Dari Pasir Kuarsa Diterima, Baristand Industri Palembang Ramadhan, A., Soegijoni, B. dan Fathurrohman, M. I., Pengaruh Organobentonit dan Asam Strearat terhadap Karakteristik Pematangan dan Sifat Mekanik Vulkanisat Karet Alam, Jurnal Penelitian Karet, 32(1):45-55, 2014

Vachlepi, A., \& Suwardin, D. (2015). Penggunaan garam ammonium dalam produksi karet viskositas rendah dari lateks. Jurnal Penelitian Karet, 33(2), 193-202.

Yuniari, A., Any, S., dan Buchori, A. 2001. Optimalisasi Kondisi Proses Vulkanisasi terhadap Sifat Fisis Kompon Karet yang Menggunakan Bahan Pengisi Jenis Silikat. Prosiding Seminar Nasional Kimia. Surakarta 